\title{
Simulasi Aliran Fluida Crude Palm Oil (CPO) dan Air Pada Pipa Horizontal Menggunakan Metode Volume Hingga \\ Bedry Yuveno Denny ${ }^{1 *}$, Yoga Satria Putra' ${ }^{1}$, Joko Sampurno ${ }^{1)}$, Agato ${ }^{2)}$
}

\author{
1) Jurusan Fisika Fakultas MIPA , Universitas Tanjungpura Pontianak \\ 2) Politeknik Negeri Pontianak \\ *Email : b_bedry@yahoo.com
}

\begin{abstract}
Abstrak
Telah dilakukan simulasi aliran dua fasa cair- cair crude palm oil (CPO) dan air yang mengalir satu arah dalam pipa horizontal untuk mendapatkan pola aliran campuran dan karakteristik aliran campuran. Penelitian ini menggunakan CPO dan air yang dialirkan melalui dua aliran masuk terpisah. Kedua aliran ini kemudian dicampurkan ke dalam pipa horizontal berdiameter $24 \mathrm{~mm}$ dan panjang $1124 \mathrm{~mm}$ yang dimodelkan secara dua dimensi menggunakan metode volume hingga. Kecepatan aliran air masuk ditentukan dengan nilai tetap sebesar 0,05 m/s dan aliran CPO divariasikan dengan nilai sebesar 0,05, 0,10 dan 0,15 m/ s. Berdasarkan hasil simulasi, diperoleh pola aliran cincin dan aliran strata licin. Nilai volume fraksi CPO pada pola aliran strata licin meningkat dengan adanya penambahan kecepatan aliran CPO. Pada pola aliran strata licin terdapat batas antar fasa dengan fluida air berada di bawah dan fluida $\mathrm{CPO}$ berada di atas. Pada kecepatan aliran $\mathrm{CPO}=0,05 \mathrm{~m} / \mathrm{s}$ batas fasa berada pada ketebalan aliran CPO 19 $\mathrm{mm}$ dengan nilai fraksi $\mathrm{CPO}$ 0,3. Pada kecepatan aliran $\mathrm{CPO}=0,10 \mathrm{~m} / \mathrm{s}$ batas fasa berada pada ketebalan $19 \mathrm{~mm}$ dengan nilai fraksi CPO 0,5. Pada kecepatan aliran $\mathrm{CP0}=0,15 \mathrm{~m} / \mathrm{s}$ batas fasa pada ketebalan 21 mm mempunyai nilai fraksi CPO 0,4. Pada hasil eksperimen menunjukan batas fasa aliran berada pada ketebalan $19 \mathrm{~mm}$ pada kecepatan $\mathrm{CPO}=0,05 \mathrm{~m} / \mathrm{s}$, batas fasa berada pada ketebalan $20 \mathrm{~mm}$ pada kecepatan aliran $\mathrm{CPO}=0,10 \mathrm{~m} / \mathrm{s}$ dan berada pada ketebalan $21 \mathrm{~mm}$ pada kecepatan aliran $\mathrm{CP} 0=0,15 \mathrm{~m} / \mathrm{s}$.
\end{abstract}

Kata Kunci : crude palm oil (CPO) dan air, pipa horizontal, pola aliran, metode volume hingga

\section{LatarBelakang}

Aliran dua fasa sering dijumpai dalam kegiatan industri seperti industri pengolahan hasil perkebunan, industri perminyakan dan gas bumi dan pipa-pipa boiler. Beberapa model aliran dua fasa diinginkan untuk terjadi dalam peralatan industri agar mendapatkan hasil produksi yang baik. Aliran dua fasa yang mengalir bersama-sama dalam pipa horizontal akan membentuk pola aliran yaitu aliran gelembung, aliran kantung gas, sumbat cairan, aliran strata licin dan strata gelombang (Colier, 1980). Pola aliran tersebut menggambarkan karakteristik dan merupakan bagian penting dari aliran dua fasa. Hal tersebut menjadikan pengetahuan tentang sifat fisik aliran dua fasa merupakan hal penting dan menarik.

Beberapa penelitian tentang aliran dua fasa yang telah dilakukan antara lain, eksperimen aliran dua fasa dari komponen minyak-air oleh Angeli dan Hewit (1999). Dua fasa dialirkan pada pipa horizontal, pola aliran yang diperoleh yaitu pola aliran stratified wavy, three layer, stratified mixed dan mixed. Balakhrisna, dkk (2010) melakukan eksperimen dalam pipa horizontal, dengan keadaan dua fasa airkerosene melewati pipa kontraksi dan ekspansi. Hasil eksperimen pola aliran yang terjadi adalah core annular flow, three layers flow, stratified flow dan dispersed flow. Irsyad (2012) melakukan penelitian tentang pengaruh aliran dua fasa gas-cair terhadap fluktuasi gaya pada dinding pipa horizontal. Hasil penelitian menunjukan bahwa gaya yang bekerja pada pipa akibat dua fasa gas- cair adalah gaya tumbukan dan gaya geser. Elseth (2001) melakukan eksperimen aliran air- minyak yang mengalir dalam pipa horizontal. Hasil eksperimen menunjukan bahwa pola aliran yang terbentuk adalah stratified flow dan dispersed flow.

CPO merupakan minyak sawit kasar dan produk utama dari hasil industri pengolahan perkebunan kelapa sawit. CPO memiliki nilai densitas yang lebih kecil dan viskositas yang lebih besar dibandingkan air. Hal ini menjadikan CPO dan air merupakan campuran yang tidak dapat menyatu, sehingga jika dialirkan dalam pipa akan terpisah dan membentuk pola aliran. Pada penelitian ini, dilakukan simulasi aliran dua fasa cair-cair CPO dan air dalam pipa horizontal. Dari simulasi akan diperoleh pola aliran sehingga akan dapat dianalisis pengaruh dari sifat fisik fluida terhadap pola aliran.

\section{Metodologi}

Model fisik dari pipa adalah pipa horizontal yang mempunyai dua sisi aliran masuk dari bawah dan satu aliran keluar di sisi lainnya. Dimensi pipa berbentuk silinder dengan panjang $1144 \mathrm{~mm}$ dan diameter $24 \mathrm{~mm}$. Geometri pipa dapat dilihat pada gambar 1. 


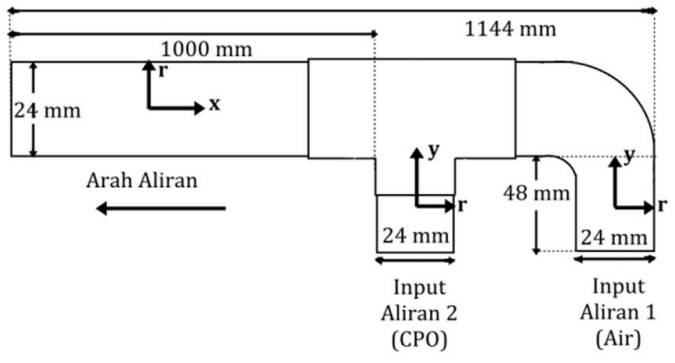

Gambar 1. Model fisik pipa horizontal

2.1 Pembuatan model pipa

Model pipa dibuat dalam dua dimensi dibagi menjadi beberapa potongan kecil yang saling menyatu (mesh). Jumlah mesh adalah 4316 buah dengan bentuk segitiga (triangular). Jumlah sisi mesh pada dinding adalah 610 sisi, 6 sisi pada aliran masuk 1, 6 sisi pada aliran masuk 2, 6 sisi pada aliran keluar, dan 6160 sisi pada bidang bagian dalam pipa. Model pipa dapat dilihat pada gambar 2 .

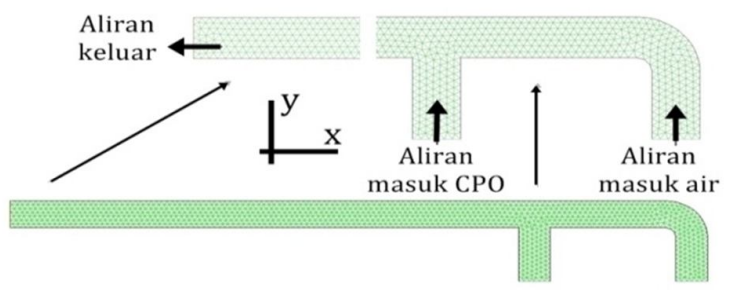

Gambar 2. Jaring volume atur pada model pipa
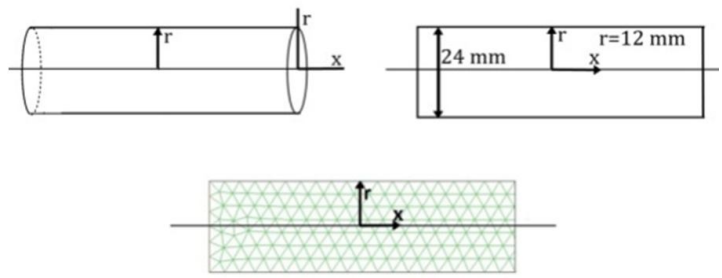

Gambar 3. Penampang bidang 2 dimensi pada model fisik pipa horizontal
Kondisi aliran berupa parameter fisik dari fluida. Kondisi aliran dapat dilihat pada tabel 1.

Tabel 1. Parameter kondisi aliran

\begin{tabular}{|l|c|c|}
\hline \multicolumn{3}{|l|}{ Sifat- sifat fluida } \\
\hline Fasa & $\rho\left(\mathrm{kg} / \mathrm{m}^{3}\right)$ & $\mu(\mathrm{kg} / \mathrm{m} . \mathrm{s})$ \\
\hline Air & 998 & 0,001 \\
\hline Cpo & 893 & 0,007 \\
\hline \multicolumn{2}{|l|}{ Kondisi aliran } \\
\hline \multicolumn{2}{|l|}{ Kecepatan aliran air (m/ s) } & 0,05 \\
\hline \multicolumn{2}{|l|}{ Kecepatan aliran cpo (m/ s) } & $0,05-0,15$ \\
\hline Gabungan antar fasa & Mixture \\
\hline $\begin{array}{l}\text { Fasa } \\
\text { Mixture }\end{array}$ & air & fasa primer \\
\cline { 2 - 3 } \multicolumn{2}{|l|}{ Model viskos } & fasa sekunder \\
\hline \multicolumn{2}{|l|}{ Mosinar } \\
\hline
\end{tabular}

\subsection{Kondisi Batas Dan Syarat Batas}

Pada proses perhitungan dan diskritisasi, kondisi batas yang digunakan adalah sebagai berikut :

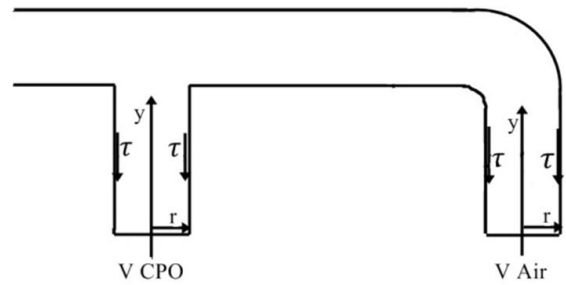

Gambar 4. Kondisi batas aliran pada aliran masuk

a) Sifat fisik fluida konstan pada aliran

$$
\frac{\partial \rho}{\partial t}=0 ; \frac{\partial P}{\partial t}=0 ; \frac{\partial v}{\partial t}=0
$$

b) Aliran air sudah terbentuk penuh

c) Efek panas akibat gesekan antar fluida dan dinding diabaikan

d) Kondisi aliran dua fasa CPO- Air adalah unsteady yaitu kondisi yang selalu berubah terhadap waktu.

Pada aliran unsteady, syarat batas yang digunakan dapat dilihat pada tabel 2.

Tabel 2. Syarat batas aliran

\begin{tabular}{|l|c|c|c|}
\hline \multicolumn{1}{|c|}{ Syarat batas } & Kondisi 1 & Kondisi 2 & Kondisi 3 \\
\hline Air, $\mathrm{V}_{\mathrm{y}}(\mathrm{m} / \mathrm{s})$ & 0,05 & 0,05 & 0,05 \\
\hline $\mathrm{CPO}, \mathrm{V}_{\mathrm{y}}(\mathrm{m} / \mathrm{s})$ & 0,05 & 0,10 & 0,15 \\
\hline Fraksi Cpo, $\mathrm{F}_{\mathrm{c}}$ & 1 & 1 & 1 \\
\hline Fraksi Air, $\mathrm{F}_{\mathrm{a}}$ & 1 & 1 & 1 \\
\hline Tegangan Geser & $\tau_{y}=\mu \frac{\partial v}{\partial y}$ & $\tau_{y}=\mu \frac{\partial v}{\partial y}$ & $\tau_{y}=\mu \frac{\partial v}{\partial y}$ \\
& $\tau_{r y}=\tau_{x r}=\mu\left(\frac{\partial u}{\partial r}+\frac{\partial v}{\partial y}\right)$ & $\tau_{r y}=\tau_{x r}=\mu\left(\frac{\partial u}{\partial r}+\frac{\partial v}{\partial y}\right)$ & $\tau_{r y}=\tau_{x r}=\mu\left(\frac{\partial u}{\partial r}+\frac{\partial v}{\partial y}\right)$ \\
\hline
\end{tabular}

e. Kondisi batas dinding

Kondisi batas aliran pada dinding dalam pipa horizontal dapat dilihat pada gambar 5 .
Kecepatan aliran searah sumbu $\mathrm{x}$. Tegangan geser berlawanan arah dengan arah sumbu $\mathrm{x}$. 


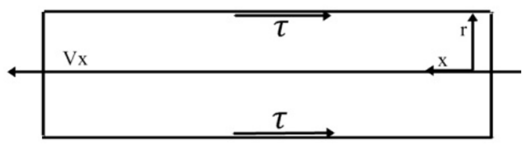

Gambar 5. Gambar kondisi batas aliran pada dinding

Kondisi batas aliran pada dinding berupa kecepatan aliran dan tegangan geser dalam arah $\mathrm{x}$. Kecepatan aliran dalam arah $\mathrm{x}$ yaitu kecepatan aliran CPO dan air. Tegangan geser pada sumbu $\mathrm{x}$ dan radial $\mathrm{r}$ ditunjukan pada pers (1) dan (2).

$$
\text { Tegangan geser, } \begin{aligned}
\tau_{x x} & =\mu \frac{\partial v}{\partial x} \\
\tau_{r x} & =\mu\left(\frac{\partial u}{\partial r}+\frac{\partial v}{\partial x}\right)
\end{aligned}
$$

2.3 Hukum kekekalan massa dan kekekalan momentum.

Kekekalan massa untuk aliran dua fasa pada koordinat kartesian ditunjukan pada pers (3) dan (4) (Philip,1985).

$$
\begin{aligned}
& \frac{\partial}{\partial t}(\rho \alpha)+\frac{\partial}{\partial x_{k}}(\rho u \alpha)=-\Phi \\
& \frac{\partial}{\partial t}(\rho \alpha)+\frac{\partial}{\partial x}\left(\rho u_{x} \alpha\right)+\frac{\partial}{\partial y}\left(\rho u_{y} \alpha\right)=0
\end{aligned}
$$

Kekekalan massa untuk pipa horizontal pada koordinat silinder ditunjukan pada pers (5)

$$
\frac{\partial}{\partial t}(\rho \alpha)+\frac{\partial}{\partial x}\left(\rho u_{x} \alpha\right)+\frac{1}{r} \frac{\partial}{\partial r}\left(r \rho u_{r} \alpha\right)=0
$$

Bidang dua dimensi dalam pipa horizontal, untuk sumbu $\mathrm{x}$ dan $\mathrm{r}$ diperlihatkan pada gambar 6.

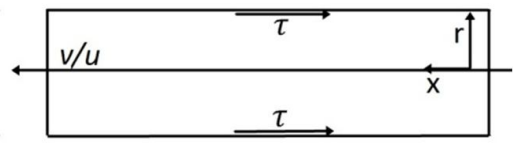

Gambar 6. Bidang untuk sumbu $\mathrm{x}$ dan $\mathrm{r}$

Persamaan momentum pada bidang dua dimensi pipa horizontal, untuk sumbu $\mathrm{x}$ dan $\mathrm{r}$ ditunjukan pada pers (6) dan (7).

$$
\begin{aligned}
& \frac{\partial}{\partial t}(\alpha \rho v)+\frac{\partial}{\partial x}\left(\alpha \rho v^{2}\right)+\frac{\partial}{\partial r}(\rho u v)=-\alpha \frac{\partial P}{\partial x}+ \\
& \frac{1}{r} \frac{\partial}{\partial r}\left(r \tau_{r x}\right)+\frac{\partial \tau_{x x}}{\partial x}+\rho g_{x} \\
& \frac{\partial}{\partial t}(\alpha \rho u)+\frac{\partial}{\partial y}(\alpha \rho u v)+\frac{\partial}{\partial r}\left(\rho u^{2}\right)=-\alpha \frac{\partial P}{\partial y}+ \\
& \frac{1}{r} \frac{\partial}{\partial r}\left(r \tau_{r r}\right)+\frac{\partial \tau_{r r}}{\partial y}+\rho g_{r}
\end{aligned}
$$

Perhitungan yang dilakukan adalah mendiskritisasi tekanan, momentum dan volume fraksi. Diskritisasi menggunakan kekekalan massa dan kekekalan momentum. Hasil simulasi dalam bentuk visual 2 dimensi, yaitu volume fraksi fasa $\mathrm{CPO}$, profil volume fraksi CPO, kontur kecepatan campuran dan profil kecepatan campuran.

\section{Hasil dan Pembahasan}

Pola aliran campuran CPO dan air diamati setiap variasi pasangan kecepatan aliran CPO dan air pada waktu tertentu. Kecepatan aliran CPO 1 yaitu $0,05 \mathrm{~m} / \mathrm{s}\left(\mathrm{V}_{\mathrm{Cl}}\right)$, kecepatan aliran $\mathrm{CPO} 2$ yaitu $0,10 \mathrm{~m} / \mathrm{s}\left(\mathrm{V}_{\mathrm{C} 2}\right)$ dan kecepatan aliran CPO 3 yaitu 0,15 m/s $\left(V_{C 3}\right)$. Kecepatan aliran air tetap yaitu $0,05 \mathrm{~m} / \mathrm{s}\left(\mathrm{V}_{\mathrm{A}}\right)$.

\subsection{Pola Aliran Campuran CPO dan Air di Sekitar} Input Aliran

Aliran campuran dua fasa terbentuk dari campuran fluida CPO dan air yang dialirkan kedalam pipa. Variasi dibuat pada setiap kecepatan aliran air yaitu $V_{A}$ dengan perubahan kecepatan aliran CPO yang semakin meningkat yaitu $\mathrm{V}_{\mathrm{C} 1}, \mathrm{~V}_{\mathrm{C} 2}$ dan $\mathrm{V}_{\mathrm{C} 3}$. Visualisasi volume fraksi CPO dalam aliran di sekitar input aliran masuk pada saat 0,5- 4,0 detik ditunjukan pada gambar 7, 8 dan 9 .

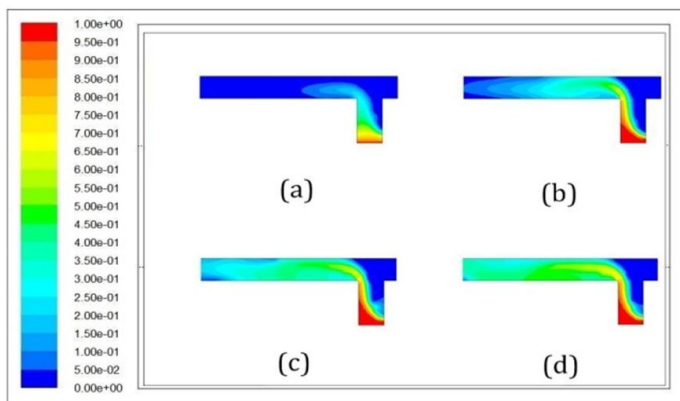

Gambar 7. Visualisasi volume fraksi CPO dalam campuran pada $\mathrm{V}_{\mathrm{C} 1}$ dan $\mathrm{V}_{\mathrm{A}}(\mathrm{a})$ saat $\mathrm{t}=0,5 \mathrm{~s}(\mathrm{~b})$ saat $t=1,5 \mathrm{~s}(\mathrm{c})$ saat $t=2,5 \mathrm{~s}(\mathrm{~d})$ Pada $t=4,0 \mathrm{~s}$

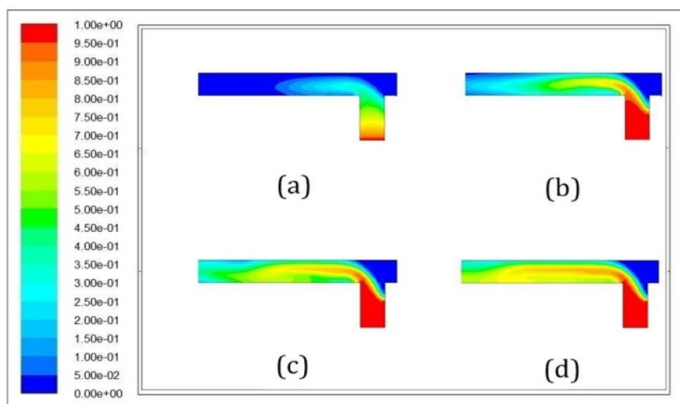

Gambar 8. Visualisasi volume fraksi CPO dalam campuran pada $\mathrm{V}_{\mathrm{C} 2}$ dan $\mathrm{V}_{\mathrm{A}}$ (a) Pada $\mathrm{t}=0,5 \mathrm{~s}(\mathrm{~b})$ Pada $t=1,5 \mathrm{~s}$ (c) Pada $t=2,5 \mathrm{~s}$ (d) Pada $t=4,0 \mathrm{~s}$ 


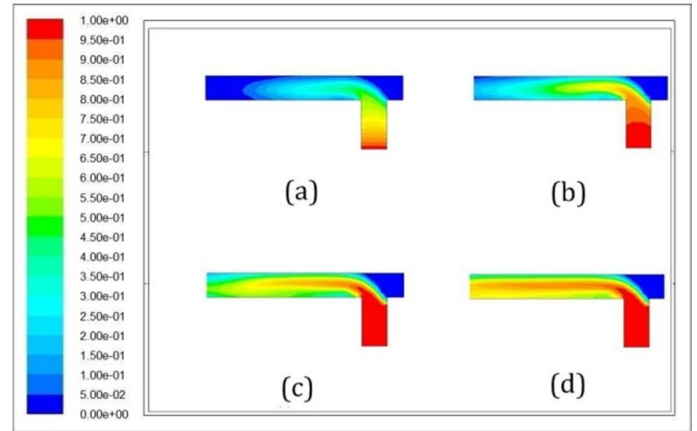

Gambar 9. Visualisasi volume fraksi CPO dalam campuran pada $\mathrm{V}_{\mathrm{C}}$ dan $\mathrm{V}_{\mathrm{A}}$ (a)Pada $\mathrm{t}=0,5 \mathrm{~s}(\mathrm{~b})$ Pada $t=1,5 \mathrm{~s}$ (c) Pada $t=2,5 \mathrm{~s}$ (d) Pada $t=4,0 \mathrm{~s}$
Pola aliran yang terbentuk adalah pola aliran cincin. Pola aliran cincin terbentuk dengan aliran CPO yang berada di tengah sementara air mengalir dan menempel pada dinding pipa. Seiring dengan penambahan kecepatan aliran CPO pola aliran cincin yang diperoleh semakin lebih halus dan fraksi CPO yang semakin meningkat.

Profil volume fraksi CPO menunjukan nilai fraksi CPO sepanjang aliran pada pipa horizontal. Profil volume fraksi CPO ditunjukan pada gambar 10, 11 dan 12 .

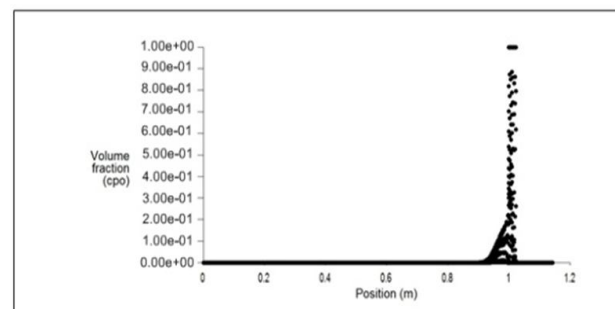

(a)

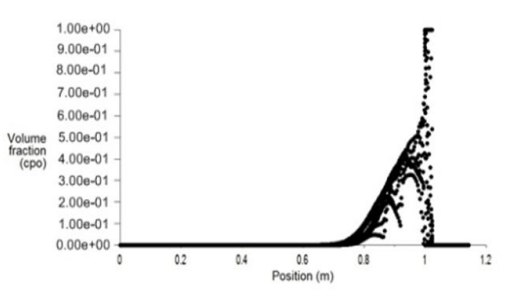

(c)

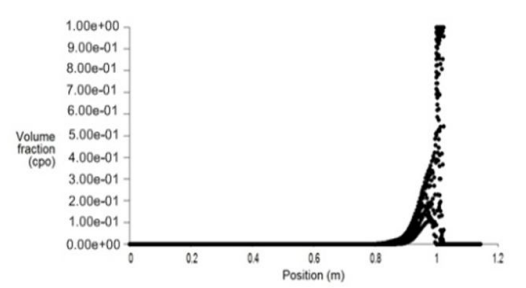

(b)

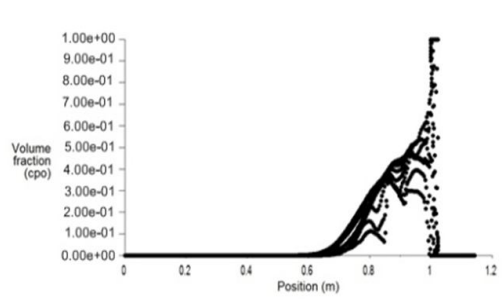

(d)

Gambar 10. Profil volume fraksi CPO sepanjang pipa horizontal pada $V_{A}$ dan $V_{C 1}(a) t=0,5 s(b) t=1,5 s(c)$ $\mathrm{t}=2,5 \mathrm{~s}(\mathrm{~d}) \mathrm{t}=4,0 \mathrm{~s}$

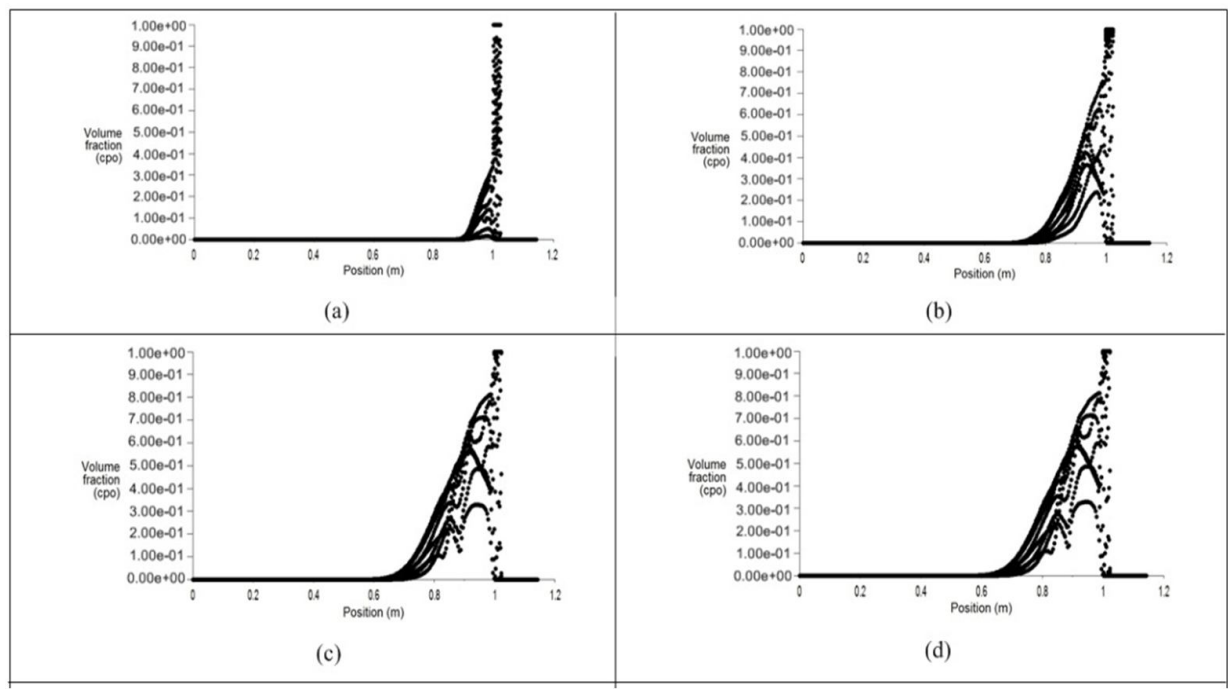

Gambar 11. Profil volume fraksi CPO sepanjang pipa horizontal pada $V_{A}$ dan $V_{C 2}(a) t=0,5 s(b) t=1,5 s(c)$ $\mathrm{t}=2,5 \mathrm{~s}(\mathrm{~d}) \mathrm{t}=4,0 \mathrm{~s}$ 


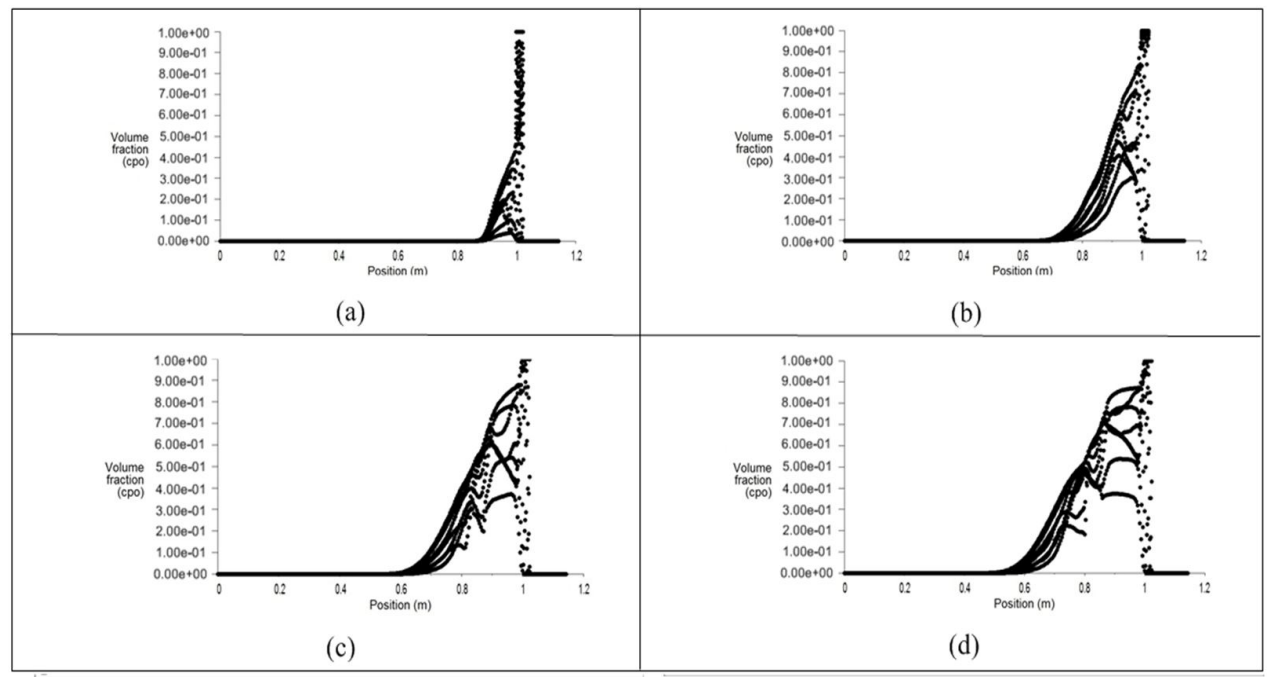

Gambar 12. Profil volume fraksi CPO sepanjang pipa horizontal pada $V_{A}$ dan $V_{C 3}(a) t=0,5 s(b) t=1,5 s(c)$ $t=2,5 \mathrm{~s}(\mathrm{~d}) \mathrm{t}=4,0 \mathrm{~s}$

Profil volume fraksi pada gambar 10,11 dan 12 menunjukan nilai fraksi CPO dalam aliran sepanjang pipa 1,144 $\mathrm{m}$. Penambahan aliran CPO pada panjang $1 \mathrm{~m}$ sebelum aliran keluar, menunjukan peningkatan nilai volume fraksi sepanjang aliran.
3.2 Kontur dan Profil Kecepatan Aliran Campuran CPO dan Air

Kecepatan aliran campuran CPO dan air dibandingkan pada saat 4 detik. Kontur profil kecepatan aliran campuran CPO dan air pada saat $\mathrm{t}=4,0$ detik pada variasi kecepatan aliran, ditunjukan pada gambar 13.

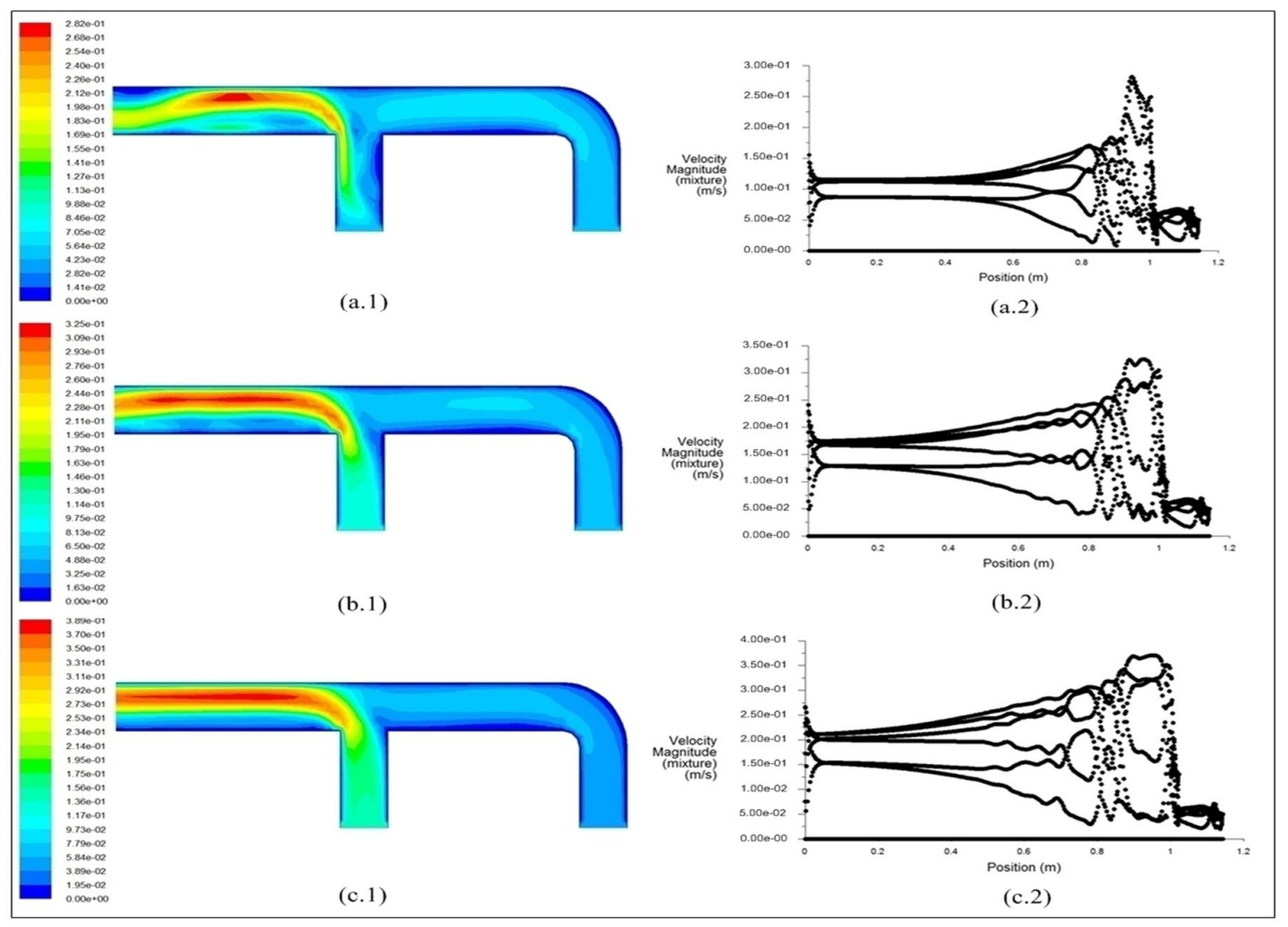

Gambar 13. Kontur kecepatan campuran dan profil kecepatan campuran CPO dan Air saat $t=4 \mathrm{~s}(\mathrm{a} .1)$ (a.2) pada $\mathrm{V}_{\mathrm{A}}$ dan $\mathrm{V}_{\mathrm{C} 1}$ (b.1) (b.2) $\mathrm{V}_{\mathrm{A}}$ dan $\mathrm{V}_{\mathrm{C} 2}$ dan (c.1) (c.2) $\mathrm{V}_{\mathrm{A}}$ dan $\mathrm{V}_{\mathrm{C} 3}$ 
Profil kecepatan aliran campuran meperlihatkan kecepatan dalam pipa sepanjang 1,144 m. Penambahan aliran CPO pada jarak $1 \mathrm{~m}$ dari ujung aliran keluar membuat kecepatan campuran mengalami perubahan. Gambar 13 (a.1), (b.1) dan (c.1) menunjukan bahwa dengan bertambahnya nilai kecepatan aliran cpo maka semakin tinggi nilai kecepatan aliran campuran. Gambar 13 (a.2), (b.2) dan (c.2) adalah profil kecepatan aliran campuran, menunjukan bahwa nilai kecepatan campuran semakin meningkat sepanjang pipa horizontal dengan adanya penambahan kecepatan aliran CPO.

\subsection{Analisis Volume Fraksi}

Nilai volume fraksi CPO dilihat pada saat 9,5, 14,5 dan 19 detik. Pola aliran setelah percabangan pipa dapat dilihat pada gambar 14 , 15 dan 16. Nilai volume fraksi CPO menunjukan pola aliran beragam. Nilai volume fraksi CPO pada kecepatan aliran air $\mathrm{V}_{\mathrm{A}}$ dan kecepatan aliran $\mathrm{CPO} \mathrm{V}_{\mathrm{C} 1}, \mathrm{~V}_{\mathrm{C} 2}$ dan $\mathrm{V}_{\mathrm{C} 3}$ ditunjukan pada gambar 14, 15 dan 16.

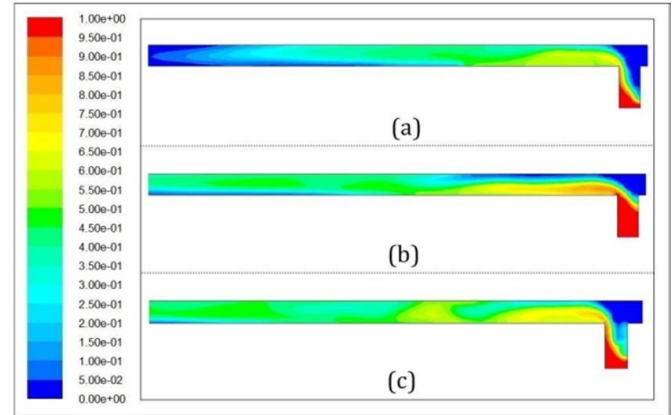

Gambar 14. Visualisasi volume fraksi CPO pada $V_{\mathrm{A}}$ dan $V_{\mathrm{Cl}}$ (a) $t=9,5 \mathrm{~s}$ (b) $t=14,5 \mathrm{~s}$ (c) $t=19,00 \mathrm{~s}$

Pola aliran pada $\mathrm{V}_{\mathrm{A}}$ dan $\mathrm{V}_{\mathrm{Cl}}$ menunjukan pola aliran yang beragam yaitu aliran sumbat liquid, strata gelombang, dan strata licin. Pola aliran yang terbentuk adalah acak dan selalu berubah setiap saat. Nilai volume fraksi CPO pada campuran bernilai rendah.

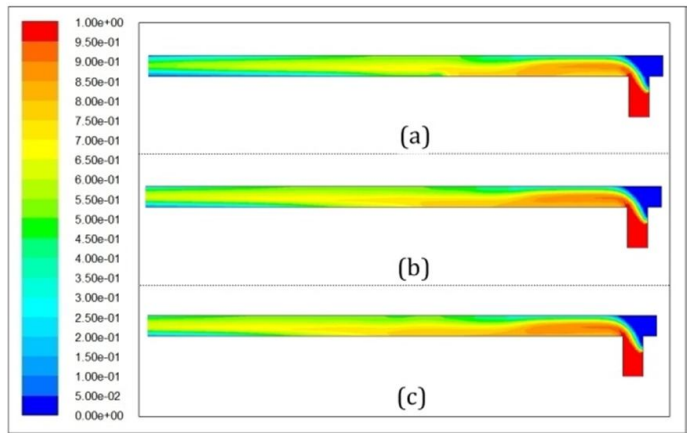

Gambar 15. Visualisasi volume fraksi CPO pada $V_{\mathrm{A}}$ dan $\mathrm{V}_{\mathrm{C} 2}$ (a) $t=9,5 \mathrm{~s}$ (b) $t=14,5 \mathrm{~s}$ (c) $t=19,00 \mathrm{~s}$

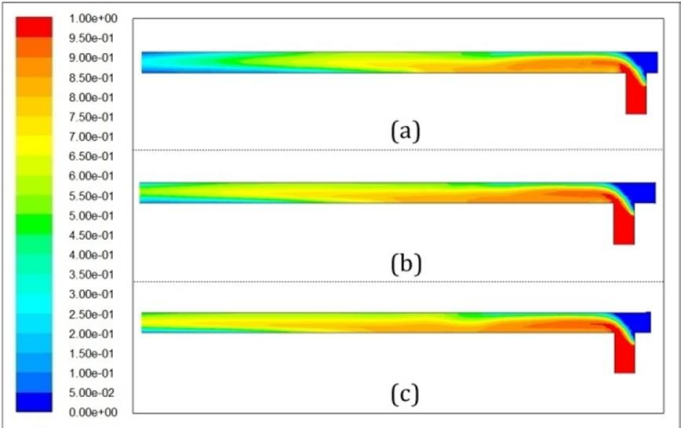

Gambar 16. Visualisasi volume fraksi CPO pada $V_{A} d_{a n} V_{C 3}(a) t=9,5 s ~(b) t=14,5 s ~(c) t=19,00 s$

Pada aliran campuran, CPO yang mengalir di bawah aliran akan naik keatas. Seiring dengan penambahan kecepatan aliran $\mathrm{CPO}_{\mathrm{C} 2}$ dan $\mathrm{V}_{\mathrm{C} 3}$ pola aliran menjadi lebih halus, terbentuk pola aliran cincin. Nilai volume fraksi CPO dalam campuran meningkat seiring dengan adanya penambahan kecepatan aliran CPO.

\subsection{Analisis Pola Aliran}

Pola aliran strata licin dan pola aliran cincin diamati pada kecepatan aliran air $\mathrm{V}_{\mathrm{A}}$ dan kecepatan aliran $\mathrm{CPO} \mathrm{V}_{\mathrm{C} 1}, \mathrm{~V}_{\mathrm{C} 2}$ dan $\mathrm{V}_{\mathrm{C} 3}$ pada saat 24 detik dan 29 detik. Pola aliran strata licin dan pola aliran cincin CPO dan Air di sekitar ujung pipa keluar ditunjukan oleh gambar 17, 18 dan 19.

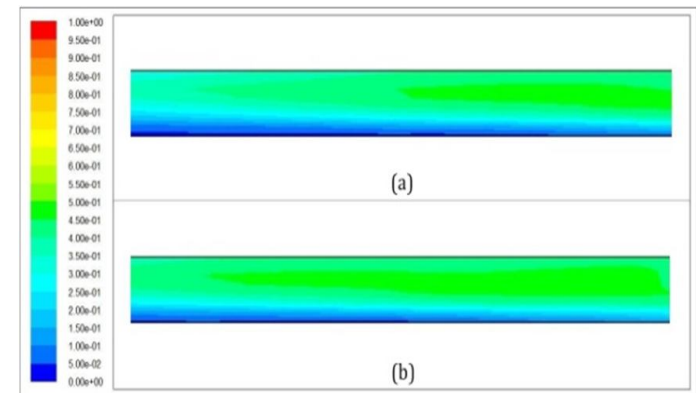

Gambar 17. Visualisasi volume fraksi CPO pada $V_{\mathrm{A}}$ dan $V_{C 1}(a) t=24 s$ (b) Pada $t=29 s$

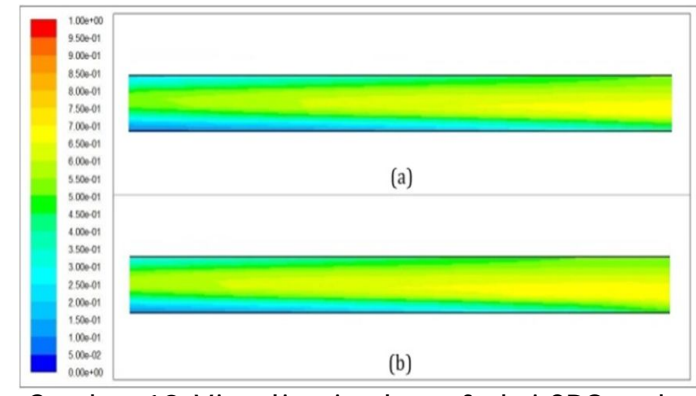

Gambar 18. Visualisasi volume fraksi CPO pada $V_{\mathrm{A}}$ dan $V_{C 2}(a) t=24 s$ (b) Pada $t=29 s$ 


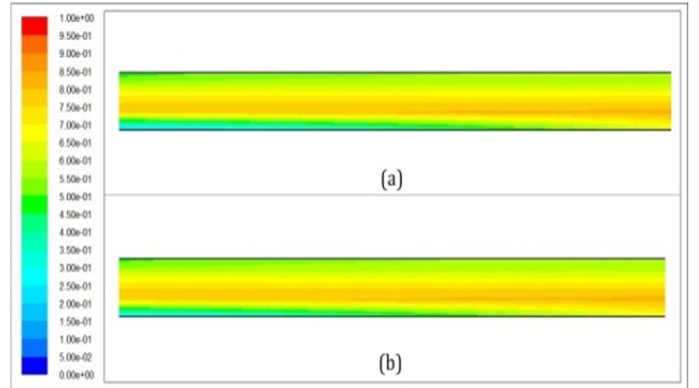

Gambar 19. Visualisasi volume fraksi CPO pada $\mathrm{V}_{\mathrm{A}}$ dan $\mathrm{V}_{\mathrm{C}}$ (a) $\mathrm{t}=24 \mathrm{~s}$ (b) Pada $\mathrm{t}=29 \mathrm{~s}$
Berdasarkan visualisasi volume fraksi CPO pada gambar 17, 18 dan 19 menunjukan bahwa pola aliran strata licin dan pola aliran cincin terbentuk di sekitar ujung pipa keluar. Nilai fraksi $\mathrm{CPO}$ meningkat dengan adanya penambahan kecepatan aliran CPO.

Percampuran antara fasa air dan CPO dapat dilihat pada nilai densitas campuran yang berada sepanjang aliran. Profil densitas campuran sepanjang aliran ditunjukan pada gambar 20.

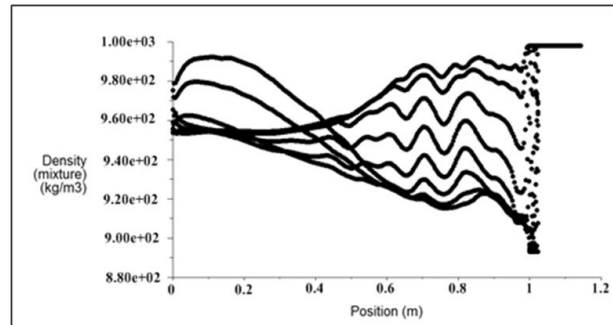

(a)

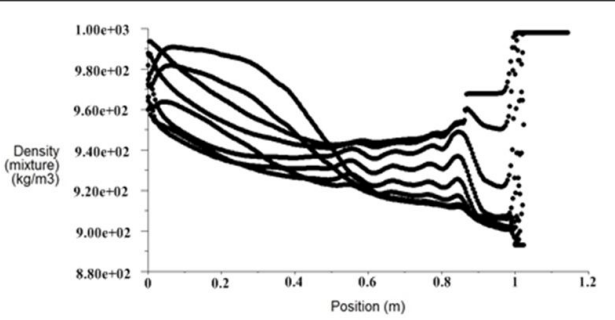

(b)

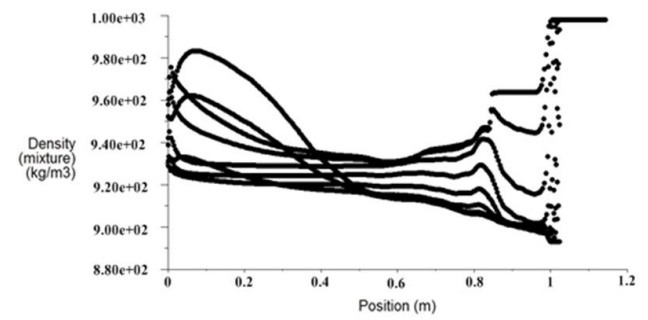

(c)

Gambar 20. Profil densitas aliran campuran Air dan CPO (a) $V_{c p o} V_{A}$ dan $V_{C 1}$ saat $t=25,5 s$ (b) $V_{A}$ dan $V_{C 2}$ saat $t=31,5 \mathrm{~s}(\mathrm{c}) \mathrm{V}_{\mathrm{A}}$ dan $\mathrm{V}_{\mathrm{C} 3}$ saat $t=28,5 \mathrm{~s}$

Profil densitas campuran pada aliran menunjukan pemisahan fasa CPO dan air. Sebelum CPO dialirkan nilai densitas tinggi. Setelah CPO dialirkan, nilai densitas campuran berkurang oleh karena aliran air bercampur dengan CPO. Pada bagian ujung pipa densitas campuran kembali tinggi yaitu densitas air, menunjukan air dan CPO terpisah.

\subsection{Pemisahan CPO dan Air Aliran Strata Licin pada Hasil Eksperimen dan Simulasi}

Pola aliran campuran $\mathrm{CPO}$ dan Air dengan kecepatan aliran air $\mathrm{V}_{\mathrm{A}}$ dan kecepatan aliran $\mathrm{CPO}$ $\mathrm{V}_{\mathrm{C} 1}, \mathrm{~V}_{\mathrm{C} 2}$ dan $\mathrm{V}_{\mathrm{C} 3}$ yang digambarkan pada pipa sebelum aliran keluar. Hasil simulasi memperlihatkan nilai volume fraksi CPO dibandingkan dengan hasil eksperimen ditunjukan pada gambar 21. Pola aliran strata licin dan aliran cincin merupakan model dari aliran dua fase yang menunjukan aliran tersebut terpisah (Koestoer, 1994). 


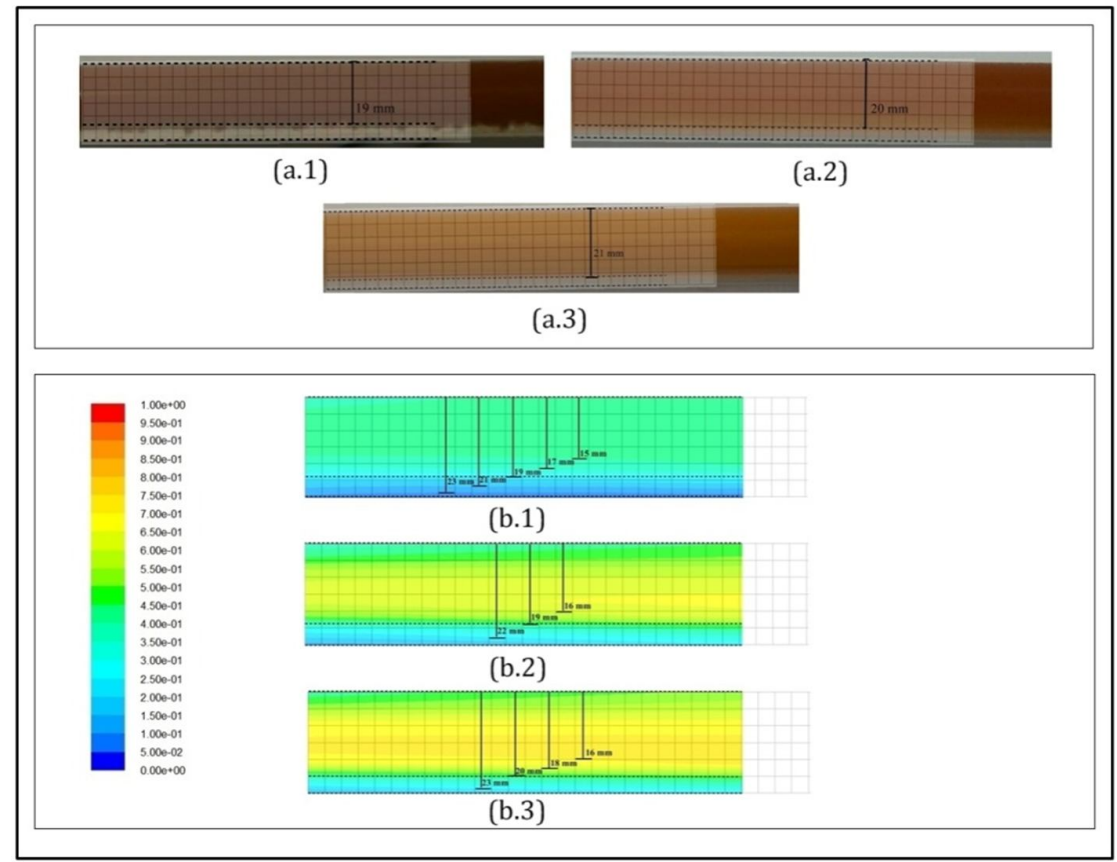

Gambar 21. Pola aliran strata licin Air dan CPO hasil eksperimen dan simulasi (a.1) (b.1)dengan $V_{\mathrm{C} 1}$ dan $\mathrm{V}_{\mathrm{A}}$ saat $\mathrm{t}=15 \mathrm{~s}$ ( $\mathrm{a}$.2) (b.2) dengan $\mathrm{V}_{\mathrm{C} 2}$ dan $\mathrm{V}_{\mathrm{A}}$ saat $14 \mathrm{~s}$ (a.3) (b.3) dengan $\mathrm{V}_{\mathrm{C} 3}$ dan $\mathrm{V}_{\mathrm{A}}$ saat $10 \mathrm{~s}$ nilai Fraksi $\mathrm{CPO}$ hasil simulasi dengan $\mathrm{V}_{\mathrm{C}}$ dan $\mathrm{V}_{\mathrm{A}}$ pada saat $\mathrm{t}=10 \mathrm{~s}$

Hasil eksperimen yang diperlihatkan pada gambar (a.1), (a.2) dan (a.3) menunjukan bahwa aliran dua fasa CPO dan air memiliki batas-batas fasa, yaitu garis antara air dan cpo yang bergerak dalam pipa. Aliran cpo memiliki warna cokelat terang hingga cokelat muda, sedangkan air memiliki warna yang lebih jernih. Tebal lapisan CPO pada hasil eksperimen dapat diperkirakan nilai tebalnya. Nilai fraksi CPO pada hasil simulasi selanjutnya dibandingkan dengan hasil eksperimen.

Pola aliran Strata licin menggambarkan aliran terpisah hasil simulasi diperlihatkan pada gambar (b.1), (b.2) dan (b.3). Pola aliran terpisah terlihat pada batas fasa CPO pada campuran. Lapisan aliran campuran CPO memiliki nilai fraksi yang cenderung sama dan memiliki ketebalan yang tinggi. Aliran campuran dengan kandungan CPO yang tinggi berada di atas dan aliran campuran dengan kandungan CPO yang rendah berada bawah. Pada gambar (b.1) yaitu pada $\mathrm{V}_{\mathrm{C} 1}$ dan $\mathrm{V}_{\mathrm{A}}$ memperlihatkan batas aliran dengan nilai fraksi cpo 0,3 berada pada tebal $19 \mathrm{~mm}$. Pada gambar (b.2), pada $\mathrm{V}_{\mathrm{C} 2}$ dan $\mathrm{V}_{\mathrm{A}}$ memperlihatkan batas dengan nilai fraksi 0,5 berada pada ketebalan $19 \mathrm{~mm}$. Pada

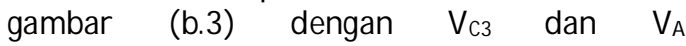
memperlihatkan batas aliran dengan nilai fraksi 0,4 pada ketebalan $21 \mathrm{~mm}$.

Hasil eksperimen pada gambar (a.1) pada $\mathrm{V}_{\mathrm{C} 1}$ dan $\mathrm{V}_{\mathrm{A}}$ memperlihatkan batas fasa aliran pada ketebalan CPO 19 mm. Pada gambar (a.2) dengan $\mathrm{V}_{\mathrm{C} 2}$ dan $\mathrm{V}_{\mathrm{A}}$ memperlihatkan batas fasa berada ketebalan CPO $20 \mathrm{~mm}$. Pada gambar (a.3) dengan $V c p o=0,15 \mathrm{~m} / \mathrm{s}$ dan Vair $=0,05 \mathrm{~m} / \mathrm{s}$ memperlihatkan batas fasa berada pada ketebalan aliran CPO $21 \mathrm{~mm}$.

Nilai fraksi dan ketebalan CPO ditunjukan oleh gambar 22(a) dan perbandingan antara hasil eksperimen dan hasil simulasi ditunjukan oleh gambar 22(b).

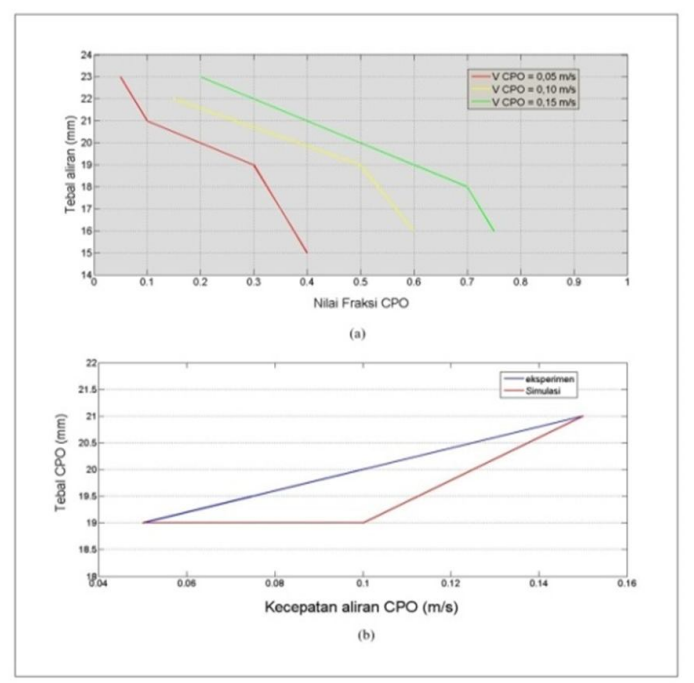

Gambar 22. (a) nilai fraksi dan ketebalan CPO pasa hasil simulasu (b) perbandingan antara hasil eksperimen dan simulasi 


\section{Kesimpulan}

Aliran dua fasa cair-cair CPO dan air dalam pipa horizontal dapat disimulasikan dalam bentuk 2 dimensi menggunakan metode volume hingga. Aliran dua fasa cair-cair CPO-Air menghasilkan pola aliran cincin dan aliran strata licin. Pola aliran terpisah fasa cair-cair ditunjukan oleh pola aliran strata licin. Semakin tinggi nilai kecepatan aliran CPO maka pola aliran campuran semakin halus dan semakin terbentuk pola aliran strata licin. Densitas CPO yang lebih rendah membuat CPO berada di atas aliran.

\section{DaftarPustaka}

Angeli, P and Hewitt, G.F., (1999), Flow Structure in Horizontal Oil-Water Flow, International Journal of Multiphase Flow, Vol-26, pp 1117-1140.

Balakhrisna, T., Ghosh, S., Das, P.K., (2010), Oilwater flows through sudden contraction and expansion in a horizontal pipe - Phase distribution and pressure drop, Int. J. Multiphase Flow 36.

Collier, J.G., (1980), Convective Boiling and Condensation, McGraw-Hill, New York.

Elseth, G., (2001), An experimental study of oil/water flow in horizontal pipes, Ph.D., Thesis, Telemark University College.

Irsyad, M., (2012), Pengaruh Aliran Dua Fasa Gas- Cair Terhadap Fluktuasi Gaya Pada Dinding Pipa Horizontal, Jurnal Mekanikal, Vol. 3 No. 1, 205-212, Teknik mesin Universitas Lampung, Lampung.

Koestoer, R.A. dan Sasanti, P., 1994, Aliran Dua Fase dan Fluks Kalor Kritis, Pradnya Paramita, Jakarta.

Philip, M.G., 1985, Fundamental of Fluid Mechanics, Addison-Wesley Publishing Company,USA. 